\title{
INFLUENCE OF UPWELLING AND TROPICAL ENVIRONMENTS ON THE BREEDING DEVELOPMENT OF THE INTERTIDAL BARNACLE Tetraclita stalactifera (Lamarck, 1818)
}

\author{
Luis Felipe Skinner ${ }^{1 *}$, Hariana Kelen Lisboa Macharet ${ }^{1}$ and Ricardo Coutinho ${ }^{2}$ \\ ${ }^{1}$ Universidade do Estado do Rio de Janeiro \\ Laboratório de Ecologia e Dinâmica Bêntica Marinha - FFP-DCIEN \\ (Rua Francisco Portela, 1470, 24435-005 São Gonçalo, RJ, Brasil) \\ ${ }^{2}$ Instituto de Estudos do Mar Almirante Paulo Moreira \\ Laboratório de Bioincrustação \\ (Rua Kioto, 253, 28930-000 Arraial do Cabo, RJ, Brasil) \\ *Corresponding author: 1skinner@uerj.br
}

\begin{abstract}
A B S TR A C T
Cabo Frio, with its unique oceanographic conditions, is an important biogeographical transitional region between tropical and sub-tropical waters. This is due to the presence of upwelling from the Central Water of the South Atlantic (CWSA), and the presence of tropical waters from the Brazilian Current (BC) and Coastal Water (CW). The intertidal barnacle, Tetraclita stalactifera, and its brooding stages were analyzed to correlate environmental conditions with reproductive development. Two thermal contrasting sites were chosen: Ponta da Cabeça (PC), which is under the influence of seasonal upwelling, and Ponta da Fortaleza (PF) which experiences tropical influences. At each site, $T$. stalactifera specimens were collected monthly and their egg lamellae conditions classified into stages from 0 (empty) to IV (ready to release). Our results show a seasonal effect on brooding at the PC site and a continuous development at the PF site. Nauplii larval availability also followed this trend. Differences between the sites could be due to ecological differences related to water temperature and the ecological-physiological response of the barnacles to these differences.
\end{abstract}

\section{R ESUMO}

Cabo Frio, devido suas características oceanográficas, causado pela é uma importante região biogeográfica transicional entre águas tropicais e sub-tropicais. Isto é ressurgência da Água Central do Atlântico Sul (ACAS) e a presença de águas tropicais da Corrente do Brasil (CB) e de Água Costeira (AC). A craca do mediolitoral Tetraclita stalactifera e seus estágios de maturação larval foram analisados a fim de serem correlacionados às condições ambientais. Dois locais com características termais contrastantes foram escolhidos: a Ponta da Cabeça (PC), que está sobre influência sazonal da ressurgência e a Ponta da Fortaleza (PF), sob influência da água tropical. Em cada local, indivíduos de $T$. stalactifera foram coletados mensalmente e a condição de suas lamellas ovígeras aferida e classificada desde o estágio 0 (vazio) até o IV (prestes a liberar). Nossos resultados amostram um efeito sazonal na PC, enquanto no local PF foi identificado um desenvolvimento contínuo. A disponibilidade de larvas náuplios também segue esta tendência. As diferenças observadas entre os locais podem ser explicadas pelas diferenças na temperatura da água e as respostas eco-fisiológicas exibidas por $T$. stalactifera na região.

Descriptors: Reproductive cycle, Tetraclita stalactifera, Cabo Frio, Upwelling. Descritores: Ciclo reprodutivo, Tetraclita stalactifera, Cabo Frio, Ressurgência.

\section{INTRODUCTION}

Reproduction is one of the most important events in the life cycle of all organisms and can be influenced by environmental conditions and the organism's physiological state (BEGON et al., 1996). In marine invertebrates, the reproductive process must be highly synchronized to ensure success and, ultimately, this synchronization is at the level of gamete development and spawning between individuals in a population (LAWRENCE; SOAME, 2004).

Environmental characteristics influence animal behavior, physiology, and basic activities such as food intake and energy storage. Energy from metabolism is used for maintenance and 
developmental activities such as growth and reproduction (BROCKINGTON; CLARKE， 2001; SCHMIDT-NIELSEN, 2002). For many marine invertebrates, gonad development is regulated by food availability and storage in order to ensure the best performance (CARVALHO; VENTURA, 2002; PODOLSKY, 2003). As an example of bottom-up control of reproduction, environmental variables also have a strong influence on both the net and gross primary production, which is important for filtering invertebrates (LESLIE et al., 2005).

Latitudinal differences are associated with differences in environmental conditions, which could affect not only animal behavior and physiology, but also the overall distribution of populations (HOEGH; PEARSE, 1995; O'RIORDAN et al., 1995; WETHEY, 2002; HERBERT et al., 2003). Sometimes, these environmental changes occur seasonally, and thus, the resulting changes in animal physiology are seasonally regulated. This seasonality must be internalized by the organism to ensure the best reproductive performance. At Cabo Frio, upwelling phenomena produce seasonally different sites in relatively close proximity, with respect to water temperature and food availability. In fact, the differences between these environmentally unique sites can be detected at an inter-site distance of only a few kilometers (VALENTIN et al., 1987; CARBONELL; VALENTIN, 1999).

Barnacles are excellent species for this kind of evaluation, because they are filtering organisms, reproduce sexually, brood their embryos up to larval release, and their larval stages are easily collected and identified using plankton trawls (BARNES, 1999). Among barnacles, Tetraclita stalactifera (LAMARCK, 1818) is found on the Brazilian coast, from Maranhão to Rio Grande do Sul, in the intertidal zone only (YOUNG, 1998). Malusa (1986) suggested that spring and summer, when water temperature is higher, constitute the breeding season for $T$. stalactifera in the Gulf of California. However, no studies of $T$. stalactifera reproduction have been conducted on the Brazilian coast. Because barnacle larval availability and settlement are seasonally related to upwelling in the region (SKINNER; COUTINHO, 2002), we wanted to investigate the seasonality of $T$. stalactifera reproductive development, and in particular, the influence of two contrasting environments: upwelling and tropical conditions.

The objective of this study was to ascertain whether the breeding cycle of $T$. stalactifera is seasonally regulated by upwelling, even at a tropical site.

The hypothesis we tested was as follows: we propose that upwelling influences the reproduction of Tetraclita stalactifera, promoting seasonal effects, whereas at the tropical site no seasonal influences should be identifiable, thus allowing for continuous reproduction.

\section{Material and Methods}

Site Descriptions and Environmental Data Acquisition

Beginning in November, 2001 through August, 2002, intertidal barnacles, Tetraclita stalactifera, were collected from a rocky shore intertidal zone on Arraial do Cabo, at two sites with differential exposure to upwelling events. The sample sites were: 1) Ponta da Cabeça (PC - $22^{\circ} 58.7^{\prime} \mathrm{S}, 042^{\circ}$ $02^{\prime} \mathrm{W}$ ), which is under the influence of upwelling, and 2) Ponta da Fortaleza (PF - $22^{\circ} 58,1^{\prime} \mathrm{S}, 042^{\circ} 00,8^{\prime} \mathrm{W}$ ), which is under tropical influence. Interestingly, these two contrasting sites are only $7 \mathrm{~km}$ (by navigational distance) or circa $2 \mathrm{~km}$ (as the crow flies) from each other. The mean tidal range in this region is $0.68 \mathrm{~m}$, and the maximum tidal amplitude $1.3 \mathrm{~m}$ (DHN, 2001/2002).

Surface seawater temperature (SST) was monitored twice a month using a Thermosalinometer (YSI 65) to detect upwelling and tropical influences. Data were used to establish a relationship between upwelling and non-upwelling times and $T$. stalactifera breeding status.

Barnacle Sampling and Breeding Stage Assessment

Barnacles were scraped monthly from natural substrata in the $T$. stalactifera zone $(0.6-0.8 \mathrm{~m}$ tidal level). A minimum of 20 individual barnacles were collected and fixed in $4 \%$ formalin solution. In the laboratory, individual barnacles were dissected under a stereoscopic microscope and developmental status was evaluated using a method adapted from O'Riordan (1995) for T. stalactifera. This method is nearly identical to that used by Satheesh and Wesley (2009) for Amphibalanus amphitrite. Breeding status was divided into five stages: stage $\mathbf{0}$, no visible embryos in the mantle space - or empty; stage $\boldsymbol{I}$, some visible embryos and bright yellow lamellae; stage $\boldsymbol{I I}$, dark yellow or orange lamellae of increased size and embryos visible to the naked eye; stage III dark beige/brown lamellae and larger embryos; stage $\boldsymbol{I V}$, grey lamellae and visible larvae. At this stage larvae are ready to be released. Collected barnacles were classified into one of these developmental stages.

The number of individuals classified in each stage in a month was obtained and transformed into a percentage of the total. Breeding season was determined by the presence of a large percentage of individuals with fertilized eggs (SATHEESH; WESLEY, 2009). The chi-squared $\left(\mathrm{X}^{2}\right)$ test was 
applied to the number of individuals in each brooding stage, using as expected values the total number of individuals collected in a month divided by number of stages (five). Also, a gonad index score (SATHEESH; WESLEY, 2009) was assigned to each stage and the weighted average gonad index was calculated as:

Condition of the Ovary/Mantle cavity

Gonad index score

Stage 0: ovary not seen

Stage I: ovary with developing ova

Stage II: ovigerous lamella with fertilized eggs 2

Stage III: ovigerous lamella with nauplii inside 3

Stage IV: free nauplii in the mantle cavity

Also, two replicates of plankton samples $(150 \mathrm{~L}, 150 \mu \mathrm{m}$ mesh size) were collected at each site twice a month for comparison of larval availability, larval release, and brood status of the adults.

\section{RESULTS}

Water Temperature and Upwelling Seasonality

SST (Fig. 1) varied at the PF site from $20^{\circ} \mathrm{C}$ (January 2002) to $26^{\circ} \mathrm{C}$ (May 2002), and at PC site from $15^{\circ} \mathrm{C}$ (December 2001) to $25^{\circ} \mathrm{C}$ (May and July 2002). The average water temperature was higher at
$\mathrm{PF}$ than at $\mathrm{PC}\left(23.3\right.$ and $19.9^{\circ} \mathrm{C}$ respectively), with a seasonal pattern at $\mathrm{PC}$, with colder water present from November until April and warmer water from April to September. Upwelling waters are characterized by SST below $20^{\circ} \mathrm{C}$ and at the PF site we did not record any SST lower than this.

\section{Assessment of Breeding Status}

A total of 429 T. stalactifera barnacles were collected; 239 at PC and 190 at the PF site. The percentage of $T$. stalactifera bearing eggs in different brooding stages was higher than $70 \%$ for barnacles collected at the PC site and lower than $60 \%$ for barnacles collected at the PF site (Fig. 2).

The frequency distribution of embryo developmental stages shows differences between the PC and PF sites (Fig. 2). At the PC site, we observed a seasonal and modal distribution of embryo developmental stages up to stage IV, indicative of seasonal brooding, whereas at the PF site, each of the five stages was recorded with equal frequencies of around $20 \%$, except for stage 0 (usually observed with a frequency higher than $20 \%$ ) and $I$ (only in March), indicating continuous, year-round brooding. Embryos in the pre-hatched stage (IV) were seen more frequently in February at the PC site and in November at the PF site.

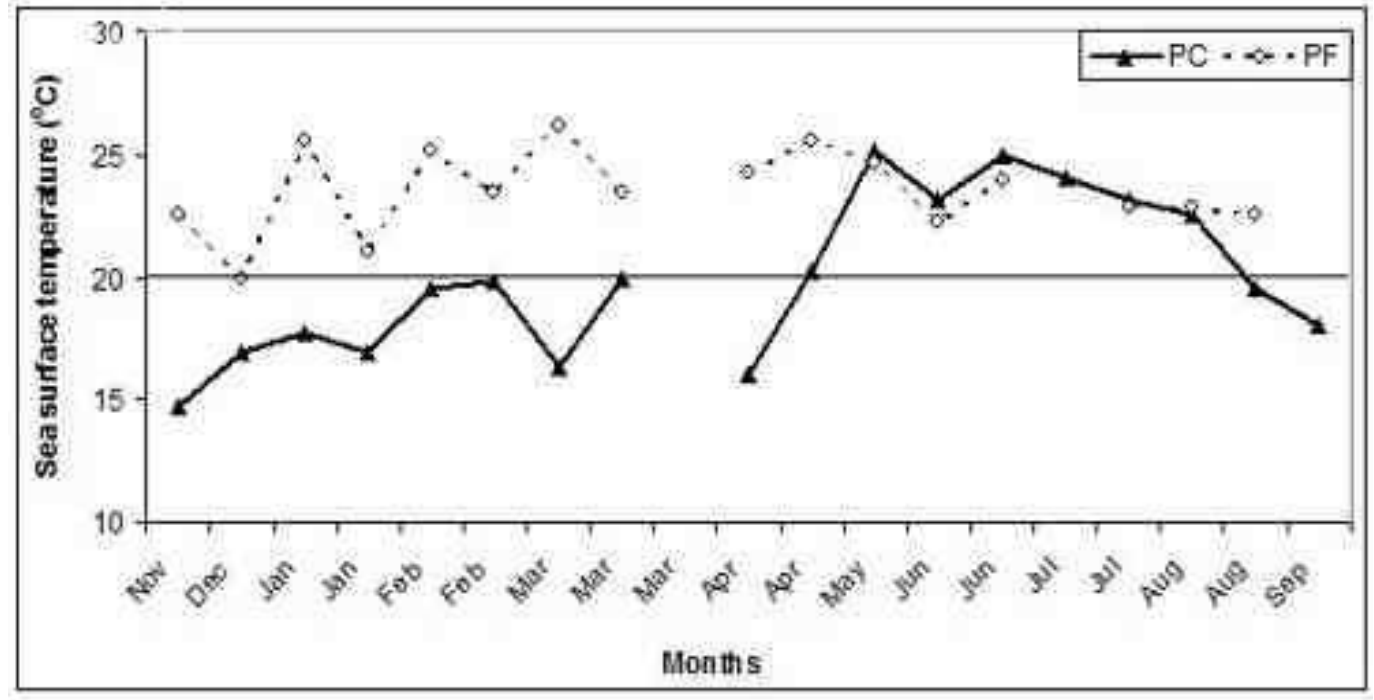

Fig. 1. Surface seawater temperatures $\left({ }^{\circ} \mathrm{C}\right)$ measured at Upwelling (Ponta da Cabeça - PC) and Tropical (Ponta da Fortaleza - PF) sites from November 2001 through September 2002. Temperatures below 20 ${ }^{\circ} \mathrm{C}$; (horizontal line) indicate upwelling events. 

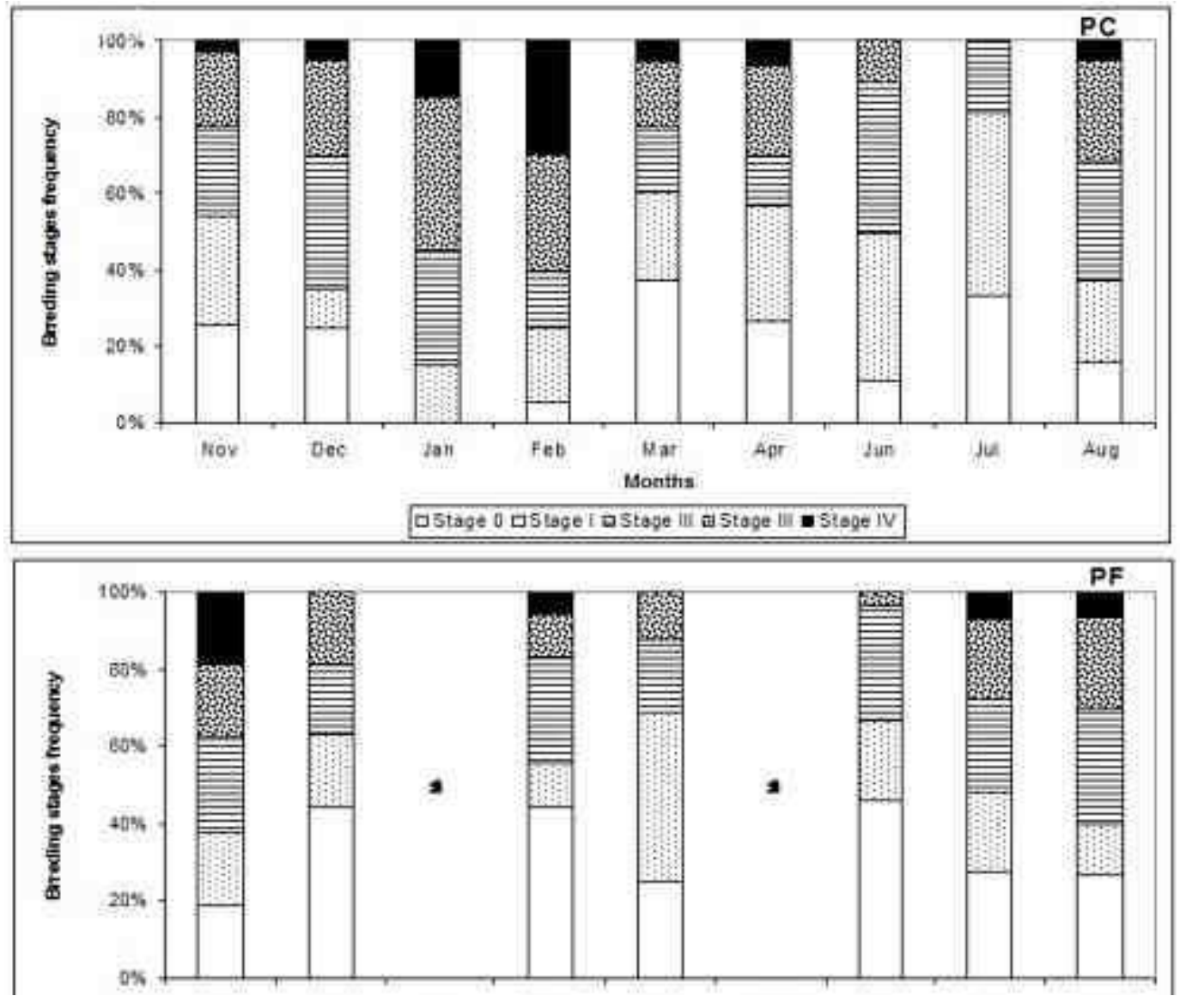

* denotes sampling not performed due to ocean conditions.

Fig. 2. Frequency (\%) of occurrence of each Tetraclita stalactifera breeding stage ( $O$ up to $I V)$ at Upwelling (PC) and Tropical (PF) sites from November 2001 to August 2002.

At the PC site, developing embryos were categorized according to frequency, as observed from November until March. From March onward, an increase in the frequency of stages $I, I I, I I I, I V$ and $\boldsymbol{O}$ was registered. Higher frequencies of developmental stages I, II, III and IV occurred in November (30\%), December (35\%), January (40\%) and February (30\%), respectively. In June and July, no individual barnacle was recorded to be at stage $I I I$ or $I V$ and these stages did not appear again until August. In February and March, we recorded two opposite and important observations. First, the lowest frequency of barnacles at stage $\boldsymbol{O}$ was observed (along with the highest frequency of individuals at stage $\boldsymbol{I V}$ ), followed by recordings of the highest frequency of barnacles at stage $\boldsymbol{O}$ (with few remaining at stage $I V$ ). Also, at this site, gonad development (stage $I$ ) started in December and continued until July, and larval release (late stage $\boldsymbol{I V}$ ) occurred from November (early release) up until April (late release). It was observed that reproductive development starts in all months but the frequency of development was seasonally regulated.

At the PF site, this pattern was not observed; all developmental stages remained nearly constant (around 20\%) and few individuals reached developmental stage $I V$ from November to August. Stage $I V$ was not recorded in December, March or June, indicating a low frequency of individuals achieving late developmental stages.

Gonad index score results (Fig. 3) are different for both sites. At the upwelling site, the gonad index increased from November 2001 through February 2002 and decreased from March up to August. This is associated with upwelling and nonupwelling season. At the same time, the gonad index for the tropical site decreased or remained lower than value two most of the time, indicating few individuals in stages III and IV.

A chi-squared test applied for the frequencies of individuals at each reproductive stage 
showed significant differences between the PC site $\left(X^{2}=355.72 ; 32 \mathrm{df} ; \mathrm{P}<0.0001\right)$ and the $\mathbf{P F}$ site $\left(X^{2}=168.60 ; 24\right.$ df; $\left.\mathrm{P}<0.0001\right)$

Plankton samples (Fig. 4) show a pattern similar to that recorded for barnacle breeding status at both sites. At the PC site, our results indicate a clearly seasonal pattern, with higher densities of nauplii larvae recorded in December and March (mean number of 300 larvae. $\mathrm{m}^{-3}$ ), and decreasing in later months (down to zero in September). In addition, in February, higher larval availability correlates with the higher frequency of brooding individuals observed to be at stage $I V$.

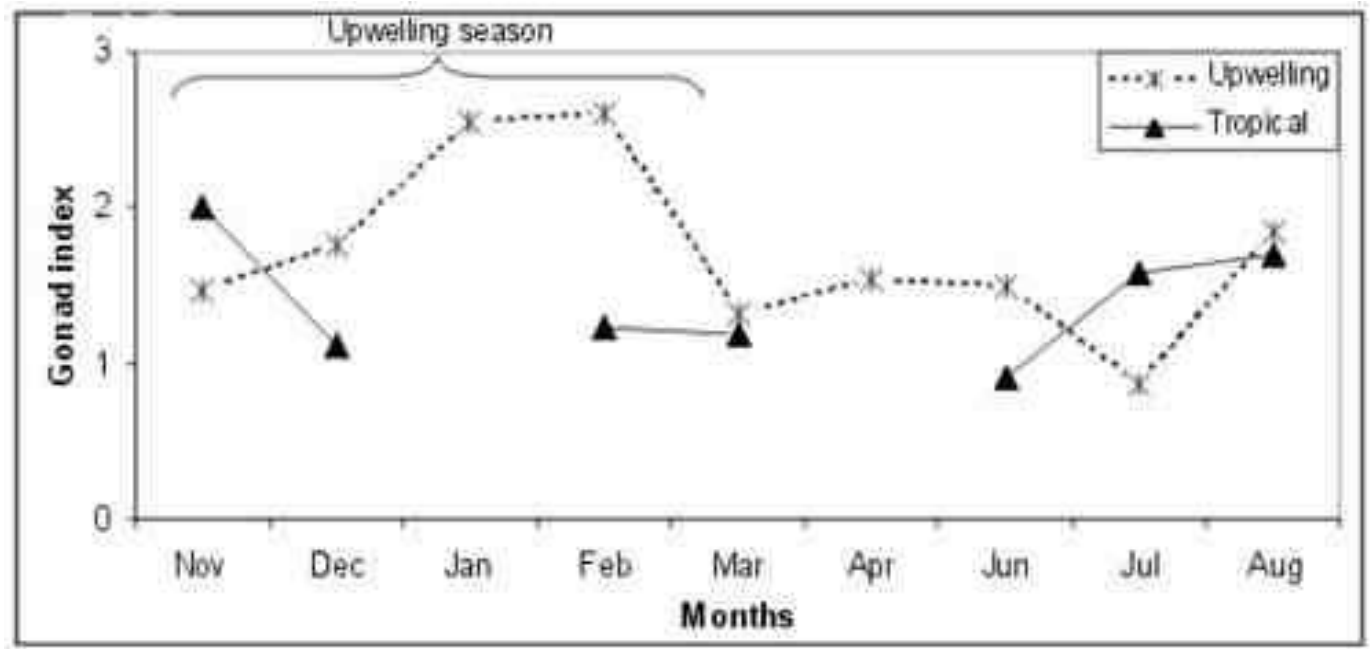

Fig. 3. Temporal variability of gonad index of Tetraclita stalactifera for Upwelling site (dashed line, *) and Tropical site (continuous line, $\boldsymbol{\Delta}$ )

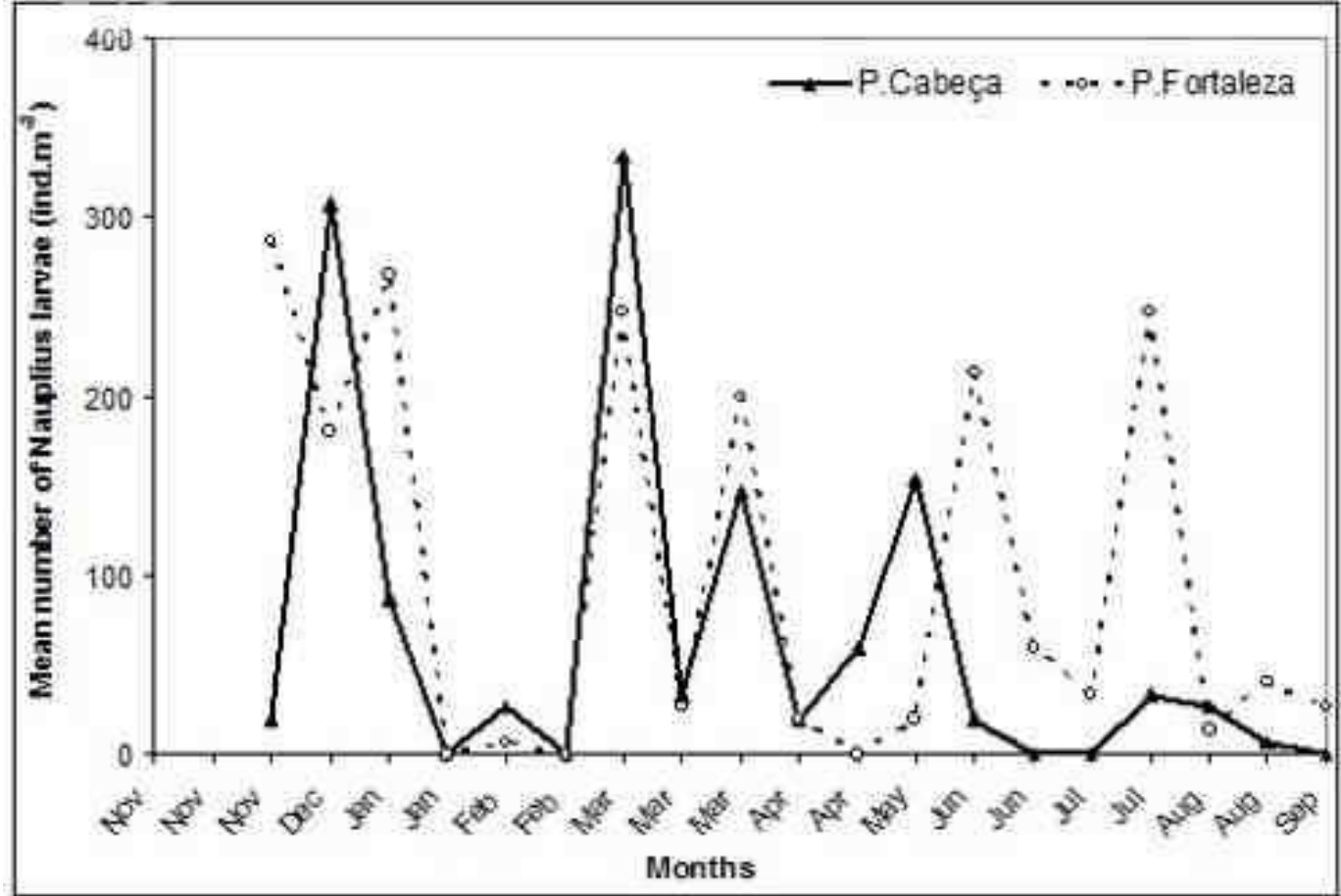

Fig. 4. Mean number of barnacle nauplius larvae (ind. $\mathrm{m}^{-3}$ ) collected at upwelling (PC - solid line) and at Tropical (PF - dotted line) from November 2001 to September 2002. 
At the PF site, high larval availability was recorded all year round (Fig. 4), with a pattern of 1 week of somewhat higher densities followed by 3 weeks of somewhat lower densities. This pattern also coincides with the higher observed frequency of brooders in stage $I V$ in November and February, and the absence of individuals at stage IV in December and March.

\section{Discussion}

Egg developmental stages of Tetraclita stalactifera, here used as markers of the reproductive cycle, and barnacle larval release/availability at Cabo Frio, show important differences between the two contrasting sites. One site is under the influence of upwelling, and a seasonal pattern was observed, whereas the other site is under tropical influences, and continuous development and larval release was recorded.

In this region, oceanographic characteristics are seasonally influenced by Northeasterly winds. This occurs from September to April (Spring/Summer), generating upwelling and, under these conditions, thermal variation is one of the most important environmental characteristics and could be easily measured. This thermal variation also correlates with phytoplankton productivity and water transport (VALENTIN et al., 1987; GONZALEZRODRIGUEZ et al., 1992; VALENTIN; MONTEIRO-RIBAS, 1993; CARBONELL; VALENTIN, 1999). At the same time, part of the region remains under tropical influences, despite upwelling events (ORNELLAS; COUTINHO, 1998; GUIMARAENS; COUTINHO, 2000; ROCHA; COSTA, 2005).

The breeding pattern observed at the site under the influence of upwelling (PC), represents a physiological adjustment of reproduction. Reproduction in marine invertebrates must be highly synchronized to ensure success. Ultimately, this synchronization is at the level of gamete development and spawning between individuals in a population, and is the culmination of gametogenic development (OLIVE, 1995; LAWRENCE; SOAME, 2004). Our results indicate that this synchronization occurs in the summer months, mainly in February, when larval release is at a maximum. Many hypotheses indicate that seasonal reproduction is an evolutionarily stable strategy, because the costs for seasonal reproduction include the maintenance costs of the acquisition of energy and the allocation of that energy to reproduction (OLIVE et al., 2000).

Because barnacles have a complex life cycle, with feeding and non-feeding larvae, adjustment of reproduction, brooding and larval release to environmental conditions is very important. For nauplius larvae, food availability and water temperature also influence the development, metamorphosis and settling capacity of cyprid larvae (DESAI et al., 2006). These results agree with our observed pattern of lamellae development and larval release. In our study, during the upwelling season, low water temperatures induce larval release that coincides with high food availability in the water column. The amount of available food is important to larval development and also as a source of energy for adult gametogenesis and even for larval release (CLARE, 1995). Many other authors have recognized the importance of this variable for many other barnacle species, such as Amphibalanus amphitrite and Semibalanus balanoides (CRISP 1956; BARNES 1957; ROZAIMI; O'RIORDAN, 2003; WHITE, 2008). A higher percentage of individuals ready to release larvae in mid-summer were recorded for Chthamalus species (O'RIORDAN et al., 1995) and for T. stalactifera (MALUSA, 1986). However, contrary to our results, these patterns were related to an increase in water temperature in the spring and summer months. Other species, such as the warmer barnacle Balanus perforatus, reproduce in summer months, when water temperatures have increased (HERBERT et al., 2003). However, larval release at these sites correlates with an increase in primary production and food availability, not water temperature. In many laboratory experiments, breeding was increased by high water temperatures $(A$. amphitrite: DESAI et al., 2006; Chthamalus: YAN; MIAO, 2004) and a large food supply.

In the Cabo Frio upwelling region, seasonal reproductive patterns have been developed in many different animals, such as seastars (ALVES et al., 2002; CARVALHO; VENTURA, 2002) and seaurchins (JUNQUEIRA et al., 1997), and correlate primarily with low water temperature. These patterns are similar to that recorded here for $T$. stalactifera. With results very similar to those reported in this study, Ventura et al. (1997) observed for the seastar Astropecten brasiliensis, that gametogenic development starts in June and peaks in November with spawning occurring in December.

Water temperature could affect the reproduction of marine invertebrates and its latitudinal or seasonal effects are being established. In species of wide distribution, reproduction could occur earlier at low or middle latitudes in comparison with those of higher latitudes, despite differences in food availability (OLIVE, 1995). The presence of colder and richer waters during the spring and summer months at the upwelling site increases the amount and quality of food for the barnacles. Despite the fact that lower metabolic rates generally correlate with immersion time in low water temperatures, it is possible that because of higher air and rock 
temperatures, we observed an increase in metabolic rates leading to an increased energy allocation for gonad development and breeding. High water temperatures increased the molting rates recorded for Chthamalus malayensis and thus this energy allocation to molting processes depletes energy reserves available for reproduction (YAN; MIAO, 2004). This hypothesis might also be suggested by our data on the growth rates (SKINNER et al., 2007) and growth patterns of barnacles with respect to immersion time (CRISP; RICHARDSON, 1975).

At the PF site, which is under tropical influence, barnacles reproduce and release larvae all year long, as expected for a tropical region. For the subtidal barnacle A. amphitrite, Satheesh and Wesley (2009), working in tropical India, found continuous breeding for this species, with no seasonal influence, in agreement with our results. The small water temperature fluctuations $\left(20-25^{\circ} \mathrm{C}\right)$ increase both the metabolic rate and filtering activity. However, at this site, low primary production (GUIMARAENS COUTINHO, 2000) could reduce the energy content available for gametogenesis.

The importance of reproduction and adaptation of marine species to favorable environmental conditions is well-known. Another intertidal species from the Brazilian coast, the limpet Collisella subrugosa, also matures gonads all year round, but displays seasonality with respect to larval release, which correlates with decreases in salinity and coastal water enrichment (ROCHA-BARREIRA, 2002).

In conclusion, upwelling induces seasonality with respect to reproduction and larval release in Tetraclita stalactifera in that region, while at the tropical site, reproduction occurs continuously (at lower frequency) and larvae release is sparse. These results could provide an important monitoring approach to measure the effects of global climate change on invertebrate reproductive parameters (LAWRANCE; SOAME, 2004).

\section{ACKNOWLEDGEMENTS}

The authors would like to thank CAPES for a scholarship granted to LFS, UERJ for a scholarship to HKLM and $\mathrm{CNPq}$ for support given to RC. This manuscript was written during the $\mathrm{PhD}$ Ecology program at UERJ.

\section{REFERENCES}

ALVES, S. L. S.; PEREIRA, A. D.; VENTURA, C.R.R. Sexual and asexual reproduction of Coscinasterias tenuispina (Echinodermata: Asteroidea) from Rio de Janeiro, Brazil. Mar. Biol., v. 140, p. 95-101, 2002.
BARNES, H. Processes of restoration and synchronization in marine ecology. The spring diatom increase and the spawning of the common barnacle Balanus balanoides (L.). Année biol., Paris, v. 33, p. 68-85, 1957.

BARNES, M. Mortality of intertidal cirripedes. Oceanogr. mar. Biol. A. Rev., v. 37, p. 153-244, 1999.

BEGON, M.; HARPER, J. L.; TOWSEND, C. R. Ecology: individuals, populations and communities. Oxford: Blackwell Science, 1996

BROCKINGTON, S.; CLARKE, A. The relative influence of temperature and food on the metabolism of a marine invertebrate. J. Exp. Mar. Biol. Ecol., v 258, p 87-99, 2001

CARBONEL, C. A. A. H.; VALENTIN, J. L. Numerical modelling of phytoplankton bloom in the upwelling ecosystem of Cabo Frio (Brazil). Ecol. Model., v.116, p. 135-148, 1999.

CARVALHO, A. L. P. S.; VENTURA, C. R. R. The reproductive cycle of Asterina stellifera (Möbius) (Echinodermata: Asteroidea) in the Cabo Frio region, southeastern Brazil. Mar. Biol., v. 141,p. 947-954, 2002.

CLARE, A. S. Chemical signals in barnacles: old problems, new approaches. In: SCHRAM, F.R.; HOEG, J.T. (Ed.). New frontiers in barnacle evolution. Rotterdam: A. A. Balkema, 1995. p. 49-67.

CRISP, D. J. A substance promoting hatching and liberation of young in cirripedes. Nature, v.178,p. 263, 1956.

CRISP, D. J.; RICHARDSON, C. A. Tidally-Produced Internal Bands in the Shell of Elminius modestus Mar. Biol., v. 33, p. 155-160, 1975.

DESAI, D. V.; · ANIL, A. C.; VENKAT, K. Reproduction in Balanus amphitrite Darwin (Cirripedia: Thoracica): influence of temperature and food concentration. Mar. Biol., v. 149, p. 1431-1441, 2006 :

GUIMARAENS, M. A.; COUTINHO, R. Temporal and spatial variation of Ulva spp. and water properties in the Cabo Frio upwelling region of Brazil. Aquat. Bot., v.66, p. 101-114, 2000.

GONZALEZ-RODRIGUEZ, E.; VALENTIN, J. L; ANDRÉ, D. L.; JACOB, S. A. Upwelling and downwelling at Cabo Frio (Brazil): Comparison of biomass and primary production responses. J. Plank. Res., v 14, p 289-306, 1992

HERBERT, R. J. H.; HAWKINS, S. ; SHEADER, M. SOUTHWARD, A.J. Range extension and reproduction of the barnacle Balanus perforatus in the eastern English Channel. J. mar. biol. Ass. U. K., v. 83, p. 73-82, 2003.

HOEGH, G. O.; PEARSE, J. S. Temperature, food availability, and the development of marine invertebrate larvae. Am. Zool., v. 35, n.4, p. 415-425, 1995.

JUNQUEIRA, A. O. R.; VENTURA, C. R. R.; CARVALHO, A. L. P. S.; SCHIMDT, A. J. Population recovery of the sea urchin Lytechinus variegatus in a seagrass flat (Araruama Lagoon, Brazil): the role of recruitment in a disturbed environment. Invert. Reprod. Dev. , v. 31, n.1-3, p. 143-150, 1997.

LAWRENCE, A. J; SOAME, J. M. The effects of climate change on the reproduction of coastal invertebrates. Íbis, v.146, Suppl.1, p. 29-39, 2004.

LESLIE, H. M.; BRECK, E. N.; CHAN, F.; LUBCHENCO, J.; MENGE, B.A. Barnacle reproductive hotspots linked to nearshore ocean conditions. Proc. Natn. Acad. Sci. USA, v. 102, n.30, p.10534-10539, 2005. 
MALUSA, J. R. Life history and environment in two species of intertidal barnacles. Biol. Bull., v.170, p 409-428, 1986

ROZAIMI, M. B. J.; O'RIORDAN, R. Reproduction of intertidal barnacles. Available from: http://www.ntu.edu.sg/eee/urop/congress2003/Procee dings/proceeds.html Accessed: 07/10/2010, 2003.

OLIVE, P. J. W. Annual breeding cycles in marine invertebrates and environmental temperature: probing the proximate and ultimate causes of reproductive synchrony. J. therm. Biol., v. 20, p. 79-90, 1995.

OLIVE, P. J. W.; LEWIS, C.; BEARDALL, V. Fitness components of seasonal reproduction: an analysis using Nereis virens as a life history model. Oceanologica Acta, v.23, n.4, p. 377-389, 2000.

O'RIORDAN, R. M.; MYERS, A. A.; CROSS, T. F. The reproductive cycles of Chthamalus stellatus (Poli) and $C$. montagui Southward in south-western Ireland. J. Exp. Mar. Biol. Ecol., v. 190, p. 17-38, 1995.

ORNELLAS, A. B.; COUTINHO, R. Spatial and temporal patterns of distribution and abundance of a tropical fish assemblage in a seasonal Sargassum bed, Cabo Frio Island, Brazil. J. Fish Biol., v. 53, Suppl. A , p.198-208, 1998.

PODOLSKY, R. D. Integrating development and environment to model reproductive performance in natural populations of an intertidal gastropod. Integr. Comp. Biol., v 43, n. 3, p 450-458, 2003

ROCHA, R. M.; COSTA, L. V. G. Ascidians (Urochordata: Ascidiacea) from Arraial do Cabo, Rio de Janeiro, Brazil. Iheringia, Sér. Zool., v. 95, n.1, 57-64, 2005.

ROCHA-BARREIRA, C. A. Gonad characterization and reproductive cycle of Collisella subrugosa (Orbigny, 1846) (Gastropoda: Acmaeidae) in the northeastern Braz. J. Biol., v. 62, p. 885-895, 2002

SATHEESH, S; WESLEY, S. G. Breeding biology of the barnacle Amphibalanus amphitrite (Crustacea: Cirripedia): influence of environmental factors in a tropical coast. J. mar. biol. Ass. U. K, v.89, n.6, p.12031208, 2009.

SCHMIDT-NIELSEN, K. Fisiologia animal: adaptações e meio ambiente. São Paulo: Ed. Santos, 2002.

SKINNER, L. F.; COUTINHO, R. Preliminary results on settlement of the barnacles Tetraclita stalactifera and Chthamalus bisinuatus on a Brazilian tropical rocky shore under upwelling conditions. Invert. Reprod. Dev., v.41, n. 1-3, p. 151-156, 2002.
SKINNER, L. F; SIVIERO, F. N.; COUTINHO, R. Comparative growth of the intertidal barnacle Tetraclita stalactifera (Thoracica: Tetraclitidae) in sites influenced by upwelling and tropical conditions at the Cabo Frio region, Brazil. Rev. biol. trop. (International Journal of Tropical Biology and Conservation), v. 55, Suppl. 1, p.71-78, 2007.

VALENTIN, J. L.; ANDRÉ, D. L.; JACOB, S. A. Hydrobiology in the Cabo Frio (Brazil) upwelling: twodimensional structure and variability during a wind cycle. Continent. Shelf Res., v. 7, p. 77-88, 1987.

VALENTIN, J. L.; MONTEIRO-RIBAS W. M. Zooplankton community structure on the east-southeast Brazilian continental shelf $\left(18-23^{\circ} \mathrm{S}\right.$ latitude). Continent. Shelf Res., v. 13, p. 407-424, 1993.

VENTURA, C. R. R.; FALCÃO, A. P. C.; SANTOS, J. S.; FIORI, C. S. Reproductive cycle and feeding periodicity in the starfish Astropecten brasiliensis in the Cabo Frio upwelling ecosystem (Brazil). Invert. Reprod. Dev., v. 31, n.1-3, p. 135-141, 1997.

WETHEY, D. S. Microclimate, competition, and biogeography: the barnacle Chthamalus fragilis in New England. Integr. Comp. Biol., v. 42, p.872-880, 2002.

WHITE, N. Semibalanus balanoides. An acorn barnacle. Marine Life Information Network: Biology and Sensitivity Key Information Sub-programme [on-line]. Plymouth: Marine Biological Association of the United Kingdom. Available from: http://www.marlin.ac.uk/reproduction.php?speciesID =4328 Accessed: 07/10/2010, 2008

YAN, Y.; MIAO, S. The effect of temperature on the reproductive cycle of the tropical barnacle, Chthamalus malayensis Pilsbry (Cirripedia). Crustaceana, v. 77, n. 2, p. 205-212, 2004

YOUNG, P. S. Maxillopoda. Thecostraca. In: YOUNG, P.S. (Ed.). Catalogue of Crustacea of Brazil. Rio de Janeiro: Museu Nacional, 1998. p. 263-285. (Série Livros, n. 6)

(Manuscript received 15 October 2010; revised 05 June 2011; accepted 01 September 2011) 